\title{
Life table parameters of the woolly whitefly Aleurothrixus floccosus (Hemiptera: Aleyrodidae) and its parasitoid Cales noacki (Hymenoptera: Aphelinidae)
}

\author{
Víctor TELLO MERCADOํㅜㄹ ENZo SOLIMANO FERNÁNDEZ ${ }^{1}$ and JAN H. GILIOMEE ${ }^{2}$ \\ ${ }^{1}$ Facultad de Recursos Naturales Renovables, Universidad Arturo Prat, Avenida Arturo Prat 2120, Casilla 121, Iquique, Chile; \\ e-mail: victor.tello@unap.cl; etosolimano@hotmail.com \\ ${ }^{2}$ Centre for Invasion Biology, Dept. of Botany \& Zoology, University of Stellenbosch, 7602 South Africa; e-mail: jhg@sun.ac.za
}

Key words. Hymenoptera, Aphelinidae, Cales noacki, parasitism, life table, biological control, woolly whitefly, population ecology

\begin{abstract}
Biological parameters of the woolly whitefly Aleurothrixus floccosus (Hemiptera: Aleyrodidae) and its parasitoid Cales noacki (Hymenoptera: Aphelinidae) were determined at $25.0 \pm 2.0^{\circ} \mathrm{C}, 50.0 \pm 10.0 \% \mathrm{RH}$ and a photoperiod of $14 \mathrm{~L}: 10 \mathrm{D}$ on three different Citrus host plants. The percentage survival of $A$. floccosus ranged between 40.23 and $44.44 \%$. The highest mortality was recorded in the first nymphal instar with mortalities ranging between 36.36 and $39.39 \%$. On C. aurantifolia the total development time was $39.83 \pm 0.68$ days and the pre-oviposition, oviposition and post-oviposition periods $2.45,10.68$ and 1.68 days, respectively. Adult longevity was 15.0 days and average fecundity $73.27 \pm 9.07$ eggs. For $C$. noacki the pre-oviposition period was 0.8 days, oviposition period 4.38 days and post-oviposition period $<1$ day. Adult longevity of $C$. noacki was 5.18 days and average fecundity $31.25 \pm 2.87$ eggs. The intrinsic growth rate $\left(r_{m}\right)$ of $C$. noacki $(0.160)$ was significantly greater $(p<0.05)$ than that of $A$. floccosus $(0.076)$. The value of the finite rate of growth $(\lambda)$ was also significantly $(p<0.05)$ greater for $C$. noacki $(1.173)$ than for $A$. floccosus $(1.079)$. The larger values of $r$ and $\lambda$ recorded for $C$. noacki under experimental conditions indicate that this aphelinid has the potential to decrease populations of A. floccosus.
\end{abstract}

\section{INTRODUCTION}

There are 20 species in the genus Aleurothrixus Quaintance \& Baker 1914 of which $80 \%$ occur in the Neotropical Region (Mexico, Central and South America, Caribbean Islands). The species A. floccosus (Maskell) 1895, the citrus woolly whitefly, occurs in the following biogeographic zones: Nearctic, Neotropical, Palearctic West, Afrotropical, Palearctic East, Eastern and Pacific Islands. It is absent in Australasia and Hawaii (Evans, 2008).

The body and two pairs of membranous wings of adult females and males of these insects are covered with a white waxy substance. The adult female is about $1.5 \mathrm{~mm}$ in length with the male slightly smaller. In Chile, their host plants are orange, mandarin, lemon, grapefruit and lime. In recent years, it has also been recorded on lucuma and guava (Rojas, 2005; Luppichini et al., 2008). The eggs give rise to nymphs, which, after walking a short distance, insert their stylets into the mesophyll tissue of leaves. During their development they pass through four nymphal stages, during which thin waxy filaments are secreted that gradually cover the body. Whitefly prefer to feed and oviposit on the undersides of young leaves that sprout when their host trees are actively growing (Ripa et al., 1999; Giliomee \& Millar, 2009).

Aleurothixus floccosus is a serious pest of citrus in many parts of the world, including Chile (Katsoyannos, 1991). In the $1^{\text {st }}$ to $2^{\text {nd }}$ Regions of Chile this species can reproduce continuously throughout the year, making it a serious pest of citrus trees (Luppichini et al., 2008).

Citriculture in northern Chile occurs mainly in oasis ecosystems at Pica and Matilla ( $1^{\text {st }}$ Region of Chile). In these agro-ecosystems the average maximum temperature is $28.5^{\circ} \mathrm{C}$ and average minimum $10.8^{\circ} \mathrm{C}$. This is a favourable climate for the development and reproduction of insects, with $A$. floccosus producing seven generations per year (France et al., 2011).

Chemical control of $A$. floccosus is very inefficient (De Bach \& Rose, 1976; Longo et al., 1985; Miklasiewicz \& Walker, 1990; Chermiti \& Onnilon, 1992; Vivas, 1992; Barbagallo et al., 1993; Katsoyannos et al., 1997). Cales noacki Howard 1907 (Hym.: Aphelinidae) and Amitus spiniferus (Brethes) (Hym.: Platygastridae) are effective natural enemies and biological control agents of this pest. However, a hyperparasitoid Signiphora sp. (Hym.: Signiphoridae) of the above parasitoids has apparently made them less effective and populations of $A$. floccosus have increased. Therefore, it is necessary to study the interaction of the pest and its natural enemies over time, compare their life history parameters and evaluate the potential of $C$. noacki as a biological control agent of $A$. floccosus.

Cales noacki, a specific parasitoid of A. floccosus, is distributed from South America to Europe (Miklasiewicz \& Walker, 1990; Del-Bene \& Gargani, 1991; Chermiti \& Onnilon, 1992; Vivas, 1992; Barbagallo et al., 1993; Ulusoy \& Uygun, 1996; Katsoyannos et al., 1997). The biology of this species was studied by Vatansever \& Ulusoy (2009), who record that the developmental time of $C$. noacki females at $26^{\circ} \mathrm{C}$ is 19.1 days, lifespan of adult females 6.2 days, preoviposition period of females 0.8 days, oviposition period 6.4 days and they can each parasitize an average of 37.4 hosts. 
Various studies indicate that, of all the natural enemies, $C$. noacki is the most efficient in controlling A. floccosus (Miklasiewicz \& Walker, 1990; Del-Bene \& Gargani, 1991; Vivas, 1992; Barbagallo et al., 1993; Katsoyannos et al., 1997; Vatansever \& Ulusoy, 2009). However, few studies compare the biological parameters of the two species (Ulusoy et al., 2003; Vatansever \& Ulusoy, 2009). The aim of this study was therefore to study the life history and behaviour of $A$. floccosus and its parasitoid C. noacki under laboratory conditions, in order to determine which one is biologically the most successful in terms of rate of development, survival of the immature stages, longevity and fecundity. In addition, the effect of the three most important citrus trees in northern Chile, i.e. sweet orange, Mexican lime tree and alemow on the survival and development of A. floccosus was also evaluated.

\section{MATERIAL AND METHODS}

\section{Insect species and host plants}

Specimens of $C$. noacki were initially collected in the field in November 2011 from a population of A. floccosus in an orchard located in Pica $\left(20^{\circ} 29^{\prime}\right.$ S, $69^{\circ} 19^{\prime}$ W; 1.348 m a.s.l.), Chile. Stock cultures of $A$. floccosus were kept on three species of Citrus: sweet orange (C. sinensis), Mexican lime tree (C. aurantifolia), and alemow (C. macrophylla), in the laboratory of the Facultad de Recursos Naturales Renovables (FRNR), Tarapacá Region. $A$. floccosus from these stock cultures served as hosts for $C$. noacki. The trees in $35 \mathrm{~cm}$ deep plastic pots were obtained from nurseries in Pica. The laboratory breeding rooms were maintained at $25.0 \pm 2.0^{\circ} \mathrm{C}, 50.0 \pm 10.0 \% \mathrm{RH}$ and a photoperiod of $14 \mathrm{~L}: 10 \mathrm{D}$ for all experiments. Assays were carried out in the laboratory of FRNR between December 2011 and December 2012.

\section{Development and survival of immature stages of $\boldsymbol{A}$. floccosus}

Sixty unsexed adults of $A$. floccosus were selected and placed in $3 \mathrm{~cm}$ diameter clip-cages attached to lemon leaves and allowed to oviposit for $2 \mathrm{~h}$. The objective of this was to produce a cohort of similar aged eggs. For this experiment eight cages (one cage per leaf) distributed on two trees were used and replicated three times, with a total of 24 cages (24 leaves) on six lemon trees. Development and survival was recorded for a group of 20 eggs (replicates) on each leaf, which was marked with Indian ink (Liu \& Stansly, 1998).

\section{Longevity and fecundity of $\boldsymbol{A}$. floccosus}

For this experiment a pair (male-female) of $A$. floccosus, which had emerged not more than $14 \mathrm{~h}$ previously, was selected. Using an aspirator, this pair was transferred to a gelatin capsule attached to the abaxial surface of a leaf of $C$. sinensis. The pair was transferred, together with the cage, to a new leaf every $24 \mathrm{~h}$ until the female died. Ink was used to mark the position of the eggs on the surface of the leaf and counted daily, using a Carl Zeiss stereomicroscope Stemi SV 6 model.

Monitoring continued from the hatching of the nymphs until the adult stage. Shortly before adult emergence, a piece of leaf with the attached pupoid stage was cut from the leaves and transferred to Petri dishes containing moist paper where they were kept until the adult emerged. The adults that emerged were counted and sexed. This experiment was performed using 22 pairs (replicates) (Liu \& Stansly, 1998).

\section{Longevity and fecundity of $C$. noacki}

Eighty unsexed adult individuals of $A$. floccosus were selected at random from citrus trees. These were transferred using an aspirator into a clip cages $3 \mathrm{~cm}$ in diameter attached to the abaxial surface of leaves of Citrus aurantifolia. These adults were allowed to lay eggs for $12 \mathrm{~h}$ and when the nymphs that hatched reached nymph II, stage they were placed in cages (average of 5.2 nymphs $/ \mathrm{cm}^{2}$ ). A virgin female and male of $C$. noacki were released into each of these cages as the initial stages of the host are preferred for oviposition by this aphelinid (Luppichini et al., 2008). Mating was observed with the aid of a stereoscopic magnifying glass.

The parasitoids and leaf cage were transferred every $24 \mathrm{~h}$ to a new leaf and observations continued until the female parasitoid died (Qui et al., 2007). To determine the number of eggs laid by the parasitoid, nymphs of $A$. floccosus were observed using the xylol technique described by Bao-Li et al. (2007). The experimental unit was a group of 10 female parasitoids. Each experimental unit was replicated three times.

\section{Duration of development and survival of $\boldsymbol{C}$. noacki juveniles}

This was done using the same experimental conditions as used to determine fecundity and longevity. Twenty-two clip cages were attached to leaves of $C$. aurantifolia. Eighty unsexed adult individuals of $A$. floccosus were placed in each clip cage. They were removed after $12 \mathrm{~h}$ and the cages monitored until the nymphs reached the nymph II stage. A single pair of C. noacki was introduced into each clip cage containing, on average, 5.2 nymphs/ $\mathrm{cm}^{2}$. The parasitoids were removed after $24 \mathrm{~h}$. Apparently unparasitized nymphs were inverted to check for egg remains or un-hatched parasitoid eggs, indicating unsuccessful parasitism or infertile eggs, respectively (Garrido et al., 1978; Urbaneja et al., 2006). Fertility was calculated as the total number of parasitized nymphs divided by the number of parasitized nymphs plus the number of nymphs with infertile eggs. Parasitized nymphs were kept to determine when the adult parasitoid emerged in order to estimate developmental time, survivorship (number that emerged divided by total number parasitized) and sex ratio. To determine the sex ratio, 360 adult parasitoids that emerged from nymphs of $A$. floccosus parasitized by $C$. noacki were selected at random and their sex determined on the basis of their antennal structure (Bao-Li et al., 2007).

\section{Design and statistical analysis}

A completely randomized design was used in all the experiments. Differences in survivorship, developmental times, adult longevity and fecundity were compared using analysis of variance $(\alpha=0.05)$. Survivorship, postembryonic development and longevity data was not normally distributed, therefore, the percentage survival was normalized using the angular transformation, $\operatorname{arcosin} \sqrt{ } \times \%^{-1}$. Postembryonic development and longevity data were transformed to $\log (\mathrm{x}+1)$ prior to analysis (Zar, 2006). An analysis of variance (ANOVA) was subsequently performed and means separated using Tukey's multiple comparison test. Subsequently, all data were analyzed using Levene's test to ensure homogeneity of variance.

\section{Life table parameters}

The life table parameters of $A$. floccosus and C. noacki were calculated with the aid of a computer program written in BASIC (Abou-Setta et al., 1986). For comparing the life table parameters of the two insects, standard deviations were estimated at a confidence interval of $95 \%$ using the Jackknife method (Maia et al., 2000) available in SAS (SAS Institute, Cary, NC, USA) (La Rossa \& Kahn, 2003; Ansaloni et al., 2007). 
TABLE 1. Effect of host plant on the survival of Aleurothrixus floccosus reared in the laboratory at $25.0 \pm 2.0^{\circ} \mathrm{C}, 50.0 \pm 10.0 \% \mathrm{RH}$ and a 14L : 10D photoperiod.

\begin{tabular}{|c|c|c|c|c|c|c|c|c|}
\hline \multirow{2}{*}{ Host plant } & \multirow{2}{*}{ Egg } & \multirow{2}{*}{ Nymph I } & \multirow{2}{*}{ Nymph II } & \multirow{2}{*}{ Nymph III } & \multirow{2}{*}{ Nymph IV } & \multicolumn{2}{|c|}{ Adults } & \multirow{2}{*}{ Survival $^{1}, \%$} \\
\hline & & & & & & Female & Male & \\
\hline C. aurantifolia & 87 & 77 & 49 & 46 & 40 & 21 & 14 & $40.23 \mathrm{a}$ \\
\hline C. sinensis & 116 & 99 & 60 & 55 & 50 & 29 & 19 & $41.38 \mathrm{a}$ \\
\hline C. macrophylla & 63 & 59 & 38 & 33 & 31 & 17 & 11 & $44.44 \mathrm{a}$ \\
\hline
\end{tabular}

${ }^{1}$ Means within a column followed by the same letters do not differ significantly based on Tukey's test $(p<0.05)$.

\section{RESULTS AND DISCUSSION}

\section{Survival and development of $A$. floccosus}

Table 1 shows the survival of $A$. floccosus on different hosts (C. aurantifolia, $C$. sinesis and C. macrophylla). This was similar but varied between 40.23 and $44.44 \%$ on these three host plants $\left(F_{2,263}=0.14, P=0.8718\right)$. These values are considerably higher than those obtained by Paulson $\&$ Beardsley (1986) in a study on the development, survival and longevity of A. floccosus on Citrus limon, in which survival was only $24.18 \%$. This could be due to the quality of the host plant (as it is another citrus species) and laboratory conditions being different from those used in this study. The average mortality recorded on the three host plants was $58.27 \%$. The highest mortality occurred during the nymph I stage, with values ranging between $36.36 \%$ and $39.39 \%$ (depending on the host). These values are lower than those obtained by Paulson \& Beardsley (1986) where the highest mortality $(56.16 \%)$ was also recorded in first instar nymphs reared on lemon seedlings. Based on these results we assume that $C$. limon is not the most suitable host for A. floccosus. For the citrus blackfly, Aleurocanthus woglumi Ashby (Hemiptera: Aleyrodidae), reared on sweet orange (C. sinensis) and acid lime Tahiti (Citrus latifolia) at $27.4^{\circ} \mathrm{C}$, the mortality is 43.41 and $32.00 \%$, respectively (Pena et al., 2009).

The duration of all postembryonic stages (Table 2) did not differ significantly on the various hosts, including that of the eggs, for which the differences were nearly significant (eggs: $F_{2,263}=3.57, P=0.05$; nymph I: $F_{2,263}=2.70$, $P=0.07$; nymph II: $F_{2,263}=0.29, P=0.75$; nymph III: $F_{2,263}=0.29, P=0.50$, nymph IV: $F_{2,263}=0.11, P=0.90$, adult: $\left.F_{2,263}=0.01, P=0.99\right)$. The sessile eggs are exposed to the microclimatic conditions at the position on the leaf where they were laid. These conditions depend on factors such the morphological features of the leaf (depressions, tricomes, cavities between the midrib and secondary veins that provide refuges) (Rioja \& Vargas, 2009). The nymphal stages are mobile and may search for more favourable microhabitats. This may account for why there were slight but insignificant differences in the duration of egg stage on the three species of citrus, but not in the development of the postembryonic stages.

Duration of development of the eggs ranged between 10.97 and 11.18 days, that of nymph I between 4.69 and 5.6 days, nymph II between 3.17 and 3.6 days, nymph III between 2.91 and 3.67 days, nymph IV between 3.71 and 4.14 days, and that of egg to adult of females between 38.44 and 39.83 days.

In general, the durations of each developmental stage recorded in this study were consistent with those determined for A. floccosus by Anonymous (1977) and Passos de Carvalho (1994). That the developmental time of the egg (incubation) is longer than that of postembryonic stages is a common phenomenon in many species of aleurodids (Paulson \& Beardsley, 1986; Liu \& Stansly, 1998; Hoddle \& Soliman, 2001).

In other species of aleurodid the average developmental time is 70 days for $A$. woglumi (Pena et al., 2009), 41 days for Tetraleurodes perseae (Hoddle, 2006) and for Bemisia argentifolii 34.72-37.46 days, depending on the variety of Hibiscus (Liu \& Stansly, 1998).

\section{Oviposition of $A$. floccosus and $C$. noacki}

The oviposition period of $A$. floccosus lasted an average $10.68 \pm 1.41$ days (Table 3 ). The average rate of oviposition was $7.90 \pm 1.16$ eggs female ${ }^{-1} \cdot$ day $^{-1}$ and on average a female laid a total of $73.27 \pm 9.07$ eggs. The average preoviposition period was 2.45 days and ranged from 0 to 5 . Average adult longevity was $15.0 \pm 1.33$ days and the percentage that was female $60.63 \pm 1.70 \%$.

\section{Cales noacki}

The oviposition period lasted an average $4.38 \pm 0.38$ days (Table 3). The average oviposition rate was $7.15 \pm 0.30$

TABLE 2. Duration of the egg and postembryonic stages of Aleurothrixus floccosus $(\mathrm{n}=24)$ on three hosts at $25.0^{\circ} \mathrm{C}, 50.0 \% \mathrm{RH}$ and a photoperiod of 14L: 10D.

\begin{tabular}{lcccccc}
\hline \multirow{2}{*}{ Host plant } & \multicolumn{5}{c}{ Duration $^{1}$ (days) \pm SE } \\
\cline { 2 - 7 } & Egg & Nymph I & Nymph II & Nymph III & Nymph IV & Adult female \\
\hline C. aurantifolia & $11.18 \pm 0.15 \mathrm{a}$ & $5.33 \pm 0.32 \mathrm{a}$ & $3.17 \pm 0.33 \mathrm{a}$ & $3.54 \pm 0.42 \mathrm{a}$ & $3.89 \pm 0.49 \mathrm{a}$ & $39.83 \pm 0.68 \mathrm{a}$ \\
C. sinensis & $10.97 \pm 0.16 \mathrm{a}$ & $4.69 \pm 0.23 \mathrm{a}$ & $3.31 \pm 0.32 \mathrm{a}$ & $2.91 \pm 0.31 \mathrm{a}$ & $3.71 \pm 0.42 \mathrm{a}$ & $38.96 \pm 0.59 \mathrm{a}$ \\
C. macrophylla & $11.05 \pm 0.16 \mathrm{a}$ & $5.60 \pm 0.25 \mathrm{a}$ & $3.60 \pm 0.41 \mathrm{a}$ & $3.67 \pm 0.47 \mathrm{a}$ & $4.14 \pm 0.56 \mathrm{a}$ & $38.44 \pm 0.49 \mathrm{a}$ \\
\hline
\end{tabular}

${ }^{1}$ Means within each column followed by the same letters do not differ significantly according to Tukey's test $(p<0.05)$. Data are reported as the mean \pm standard error. 
TABLE 3. Oviposition periods, longevity, fecundity and oviposition rates of Aleurothrixus floccosus $(\mathrm{n}=22)$ and Cales noacki on Citrus sinensis at $25.0 \pm 2.0^{\circ} \mathrm{C}, 50.0 \pm 10.0 \% \mathrm{RH}$ and a photoperiod of $14 \mathrm{~L}: 10 \mathrm{D}$.

\begin{tabular}{|c|c|c|}
\hline & Aleurothrixus floccosus & Cales noacki \\
\hline Periods & & \\
\hline Preoviposition & $2.45 \pm 0.24 \mathrm{a}$ & $0.80 \pm 0.01 \mathrm{~b}$ \\
\hline Oviposition & $10.68 \pm 1.41 \mathrm{a}$ & $4.38 \pm 0.38 b$ \\
\hline Postoviposition & $1.86 \pm 0.30 \mathrm{a}$ & $0.14 \pm 0.07 \mathrm{~b}$ \\
\hline Longevity & $15.00 \pm 1.33 \mathrm{a}$ & $5.18 \pm 0.38 b$ \\
\hline Oviposition & & \\
\hline Total eggs $\cdot$ female $^{-1}$ & $73.27 \pm 9.07 \mathrm{a}$ & $31.25 \pm 2.87 \mathrm{~b}$ \\
\hline Eggs $\cdot$ female $^{-1} \cdot$ day $^{-1}$ & $7.90 \pm 1.16 \mathrm{a}$ & $7.15 \pm 0.30 \mathrm{a}$ \\
\hline
\end{tabular}

${ }^{1}$ Means within each row followed by different letters differ significantly based on Tukey's test $(\mathrm{p}<0.05)$. Data are means \pm standard errors.

eggs female ${ }^{-1} \cdot$ day $^{-1}$. Each female laid an average total of $31.25 \pm 2.87$ eggs. The pre-oviposition period was $0.8 \pm 0.01$ days, longevity was an average of $5.18 \pm 0.38$ days and proportion of females $62.00 \pm 4.90 \%$.

Peak in oviposition was reached on the second day after the beginning of oviposition, falling rapidly to end on the seventh day. Over the first three days there was no mortality and then the females rapidly started to die with $50 \%$ mortality recorded on day 5 (Fig. 1).

The data are consistent with those obtained by Onillon (1977) who determined that at $27^{\circ} \mathrm{C}$ the duration of the pre-oviposition and oviposition periods are 1.96 and 8.14 days, respectively, and total fecundity $89.03 \mathrm{eggs} \cdot \mathrm{female}^{-1}$.

At higher temperatures all processes occur significantly faster, which results in rapid ageing of the females with a significant reduction in the total number of eggs laid and a reduced longevity. In contrast, the number of eggs laid per day increases. This last parameter, together with the increased rate of embryonic and larval development, increases the potential pest status of $A$. floccosus in warm citrus-growing areas (Onillon, 1977).

\section{Life table parameters}

A. floccosus had a greater net reproduction rate $\left(R_{0}\right)$, and conversely, smaller intrinsic growth rate $\left(r_{m}\right)$ and finite growth rate $(\lambda)$ than $C$. noacki. The generation times $(T)$ of both species were statistically similar (Table 4). The life table indicates that $C$. noacki populations grow 14.1 times in 16.57 days, i.e., for each female of the current generation, 14.1 females are produced in the following generation. Furthermore, each female on any one day will result in 1.17 females the next day. Therefore, under favourable conditions, the number of females in $C$. noacki populations increases at a daily rate of about $16 \%$ (Table 4 ).

The net reproduction rate, or number of females for each female of a generation, was statistically similar for both species (Table 4), which indicates that both species have the same reproductive capacity.

Comparing the life table parameters of both species, it can be seen that there are significant differences in three of the four parameters studied (Table 4). The intrinsic growth rate $\left(r_{m}\right)$, which indicates the ability of a population to increase in abundance from generation to generation (Rabinovich, 1980), is a fundamental indicator of the potential of a parasitoid to control its host (Persad \& Khan, 2002; Stenseng et al., 2003; Vargas et al., 2005; Kontodimas et al., 2007). The $r_{m}$ parameter of $C$. noacki $(0.160)$ is greater than that of $A$. floccosus (0.076) (Table 4).

The finite growth rate $C$. noacki $(0.1173)$ is greater than that of A. floccosus (1.079) (Table 4). This indicates that the parasitoid tends to generate a higher number of individuals per day, which for a potential biological control agent is advantageous because it means it can keep the host population at a low level.

Generation time, the mean time between two successive generations is significantly longer in A. floccosus (38.769 days) than $C$. noacki (16.572 days) (Table 4) and this is interpreted as favourable for increasing the numbers and effect of the parasitoid (La Rossa et al., 2002).

It is now important to evaluate the potential of Eretmocerus paulitus Hempel and Amitus spiniferus (Brèthes)

TABLE 4. Life table parameters and statistics of Aleurothrixus floccosus reared on sweet orange (Citrus sinensis) and that of its parasitoid Cales noacki kept at $25.0 \pm 2.0^{\circ} \mathrm{C}, 50.0 \pm 10.0 \% \mathrm{RH}$ and a photoperiod of $14 \mathrm{~L}: 10 \mathrm{D}$.

\begin{tabular}{lccc}
\hline Parameter & $\mathrm{n}$ & \multicolumn{2}{c}{ Jackknife estimates of life table parameters $(95 \% \mathrm{CI})^{1}$} \\
\cline { 3 - 4 } & & Aleurothrixus floccosus & Cales noacki $^{-}$ \\
\hline Intrinsic growth rate $\left(r_{m}\right)$ & 22 & $0.076(0.070-0.082) \mathrm{b}$ & $0.160(0.154-0.166) \mathrm{a}$ \\
Net reproductive rate $\left(R_{0}\right)$ & 22 & $19.103(14.183-24.023) \mathrm{a}$ & $14.098(12.501-15.695) \mathrm{a}$ \\
Generation time $(T)$ & 22 & $38.769(37.512-40.025) \mathrm{a}$ & $16.572(16.434-16.711) \mathrm{b}$ \\
Finite growth rate $(\lambda)$ & 22 & $1.079(1.073-1.086) \mathrm{b}$ & $1.173(1.166-1.180) \mathrm{a}$ \\
\hline
\end{tabular}

${ }^{1}$ Means within each row followed by different letters differ significantly based on Tukey’s test $(\mathrm{p}<0.05)$. Data are means \pm standard errors. 


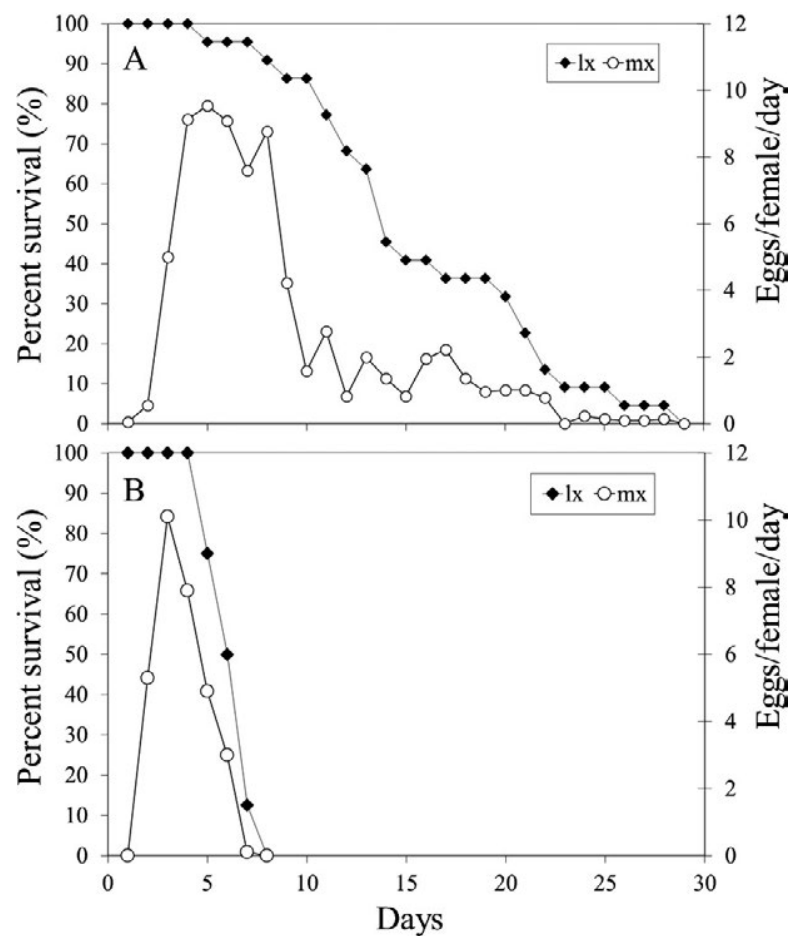

Fig. 1. Age-specific survivorship (lx) and age-specific birth rate (mx) of Aleurothrixus floccosus (A) reared on Citrus sinensis and of Cales noacki (B) parasitizing A. floccosus at $25.0 \pm 2.0^{\circ} \mathrm{C}$, $50.0 \pm 10.0 \% \mathrm{RH}$ and a photoperiod of $14 \mathrm{~L}: 10 \mathrm{D}$.

(Hym.: Platygasteridae), two other parasitoids present in northern Chile that parasitize A. floccosus, and the effect of the hyperparasitoid Signiphora sp. on both populations of primary parasitoids. This knowledge will be useful in the development of plans for the biological control or integrated pest management (IPM) of A. floccosus in the arid zones of Chile.

\section{CONCLUSIONS}

The survival of $A$. floccosus reared on sweet orange, Mexican lime tree and alemow was 40.23, 41.38 and $44.44 \%$, respectively, with no significant differences between them.

The host plant species had no significant effect on the developmental time of $A$. floccosus. Females took on average 39 days to reach the adult stage.

Aleurothrixus floccosus had a longer generation time $(T)$ and greater net reproductive rate $\left(R_{0}\right)$, but lower intrinsic growth rate $\left(r_{m}\right)$ and finite growth rate $(\lambda)$, than $C$. noaki. The higher intrinsic growth rate, lower generation time and the capacity to produce a higher number of individuals per day than $A$. floccosus indicate that the parasitoid C. noacki has the potential to be an effective biological control agent under field conditions.

\section{REFERENCES}

Abou-Setta M.M., Dorrell R.W. \& Childres C.C. 1986: Life 48: a BASIC computer program to calculate life table parameters for an insect or mites species. - Fla. Entomol. 69: 690-697.
Anonymous 1977: The fight in Spain against the woolly whitefly Aleurothrixus floccosus. - Bol. Serv. Plagas 3: 87-100 [in Spanish, English abstr.].

Ansaloni T., Aucejo S. \& Jacas J.A. 2007: Estimating the intrinsic rate of increase of Tetranychus urticae: which is the minimum number of immature individuals to consider? - Exp. Appl. Acarol. 41: 55-59.

Bao-Li Q., De Barro P.J., Ren S.X. \& Xu C.X. 2007: Effect of temperature on the life history of Eretmocerus sp. nr. furuhashii, a parasitoid of Bemisia tabaci. - BioControl. 52: 733-746.

Barbagallo S., Longo S., Rapisarda C. \& Siscaro G. 1993: Status of the biological control against citrus whiteflies and scale insects in Italy. - Proc. Int. Soc. Citricult. 3: 1216-1220.

Chermiti B. \& OnNilon J.C. 1992: About the presence in Tunisia of two new species of whitefly pests in citrus, Aleurothrixus floccosus (Maskell) and Parabemisia myricae (Kuwana) (Homoptera: Aleyrodidae). - Fruits 47: 405-411 [in Italian, English abstr.].

De Bach P. \& Rose M. 1976: Biological control of Woolly Whitefly. - Calif. Agr. 30: 4-7.

Del-Bene G. \& Gargani E. 1991: Observations on Aleurothrixus floccosus (Mask.) (Hom.: Aleyrodidae) and its antagonist Cales noacki How. (Hym. Aphelinidae) in Tuscany. - Redia 74: 11-126.

Evans G.A. 2008: The Whiteflies (Hemiptera: Aleyrodidae) of the World and their Host Plants and Natural Enemies. USDA/Animal Plant Health Inspection Service (APHIS), 703 pp.

France A., Gerding M., Tello V., Peralta O. \& Sepúlveda M. 2011: Investigation about Adaptability of Entomopathogenic Fungi in Pica. INIA Quilamapu, Universidad Arturo Prat, Iquique, 126 pp. [in Spanish].

Garrido A., Del Busto T., Tarancon J. \& Martínez M. 1978: A technique to observe immature stages of Cales noacki How. (Hym.: Aphelinidae). - Bol. Serv. Plagas 4: 35-41 [in Spanish].

Giliomee J.H. \& Millar I.M. 2009: The woolly whitefly, Aleurothrixus floccosus (Maskell) (Hemiptera: Aleyrodidae), a potentially serious citrus pest, recorded from South Africa. - Afr. Entomol. 17: 232-233.

HodDle M.S. 2006: Phenology, life tables, and reproductive biology of Tetraleurodes perseae (Hemiptera: Aleyrodidae) on California avocados. - Ann. Entomol. Soc. Am. 99: 553-559.

Hodde M.S. \& Soliman G.N. 2001: Developmental and reproductive biology of the red-banded whitefly, Tetraleurodes perseae Nakahara (Homoptera: Aleyrodidae). - Subtrop. Fruit News 8: 15-18.

Katsoyannos P. 1991: First record of Aleurothrixus floccosus (Mask.) (Homoptera: Aleyrodidae) in Greece and some observations on its phenology. - Entomol. Hell. 9: 69-72.

Katsoyannos P., Ifantis K. \& Kontodimas D.C. 1997: Phenology, population trend and natural enemies of Aleurothrixus floccosus (Hom.: Aleyrodidae) at a newly invaded area in Athens, Greece. - Entomophaga 42: 619-628.

Kontodimas D.C., Milonas P.G., Stathas G.J., Economou L.P. \& KaVAllieratos N.G. 2007: Life table parameters of the pseudococcid predators Nephus includens and Nephus bisignatus (Coleoptera: Coccinellidae). — Eur. J. Entomol. 104: 407-415.

LA Rossa R. \& KAHN Y.N. 2003: Two computer programs to make fertility life tables and calculate biological and demographic parameters in aphids (Homoptera: Aphidoidea). — RIA 32: 127-142.

La Rossa F., Crespo D. \& Lecuona R. 2002: Population parameters of Spalangia endius Walker (Hymenoptera: Pteromalidae) 
on pupae of Musca domestica L. (Diptera: Muscidae). - Neotrop. Entomol. 31: 597-600.

LiU T.X. \& STANSLY P.A. 1998: Life history of Bemisia argentifolii (Homoptera: Aleyrodidae) on Hibiscus Rosa-Sinensis (Malvacea). - Fla Entomol. 8: 437-445.

Longo S., Rapisarda C. \& Russo A. 1985: Results of the biological control of Aleurothrixus floccosus (Maskell) in citrus orchards of eastern Sicily. Atti XIV Congresso Nazionale Italiano di Entomologia sotto gli auspici dell'Academia Nazionale Italiana di Entomologia, della Societa Entomologica Italiana e della International Union of Biological Sciences, 28.v.-1.vi. 1985, Palermo, Italy. pp. 841-848.

Luppichini P., Ripa R., Larrrral P., NúÑez E. \& Rodríguez F. 2008: Woolly whitefly / woolly citrus whitefly, Aleurothrixus floccosus (Maskell). In Ripa R. \& Larral P. (eds): Pest Management in Citrus and Avocado. INIA Books Collection No. 23, pp. 111-122.

Maia A.H., Luiz A.J. \& Campanhola C. 2000: Statistical inference on associated fertility life table parameters using jackknife technique: Computational aspects. - J. Econ. Entomol. 93: $511-518$.

Miklasiewicz T.J. \& Walker G.P. 1990: Population dynamics and biological control of the Woolly Whitefly (Homoptera: Aleyrodidae) on Citrus. - Environ. Entomol. 19: 1485-1490.

ONILLON J.C. 1977: Aspects of the ecology of some aleyrodids. - Bol. Serv. Plagas 3: 175-198 [in Spanish, English abstr.].

Passos de Carvalho J. 1994: The woolly whitefly Aleurothrixus floccosus (Maskell, 1895) (Homoptera - Aleyrodidae). Instituto Nacional de Investigaçâo Agrária, Madeira, 102 pp. [in Portuguese].

Paulson G.S. \& Beardsley I.W. 1986: Development, oviposition and longevity of Aleurothrixus floccosus (Maskell) (Homoptera: Aleyrodidae). — Proc. Hawaii. Entomol. Soc. 26: 97-99.

Pena M.R., da Silva N.M., Vendramim J.D., Lourenção A.L. \& DE HADDAD M. 2009: Biology of the citrus black Aleurocanthus woglumi Ashby (Hemiptera: Aleyrodidae), in three host plants. - Neotrop. Entomol. 38: 254-261 [in Portuguese, English abstr.].

Persad A. \& Khan A. 2002: Comparison of life table parameters for Maconellicoccus hirsutus, Anagyrus kamali, Cryptolaemus montrouzieri and Scymnus coccivora. - BioControl 47: 137-149.

Qui B.L., De Barro P.J., Ren S.X. \& Xu C.X. 2007: Effect of temperature on the life history of Eretmocerus sp. nr. furuhashii, a parasitoid of Bemisia tabaci. — BioControl 52: 733-746.
RABINOVICH J.E. 1980: Introduction to the Ecology of Animal Populations. Editorial Continental, Ciudad de México, [in Spanish].

RiOJA T. \& VARGAS R. 2009: Life table parameters and consumption rate of Cydnodromus picanus Ragusa, Amblyseius graminis Chant, and Galendromus occidentalis (Nesbitt) on avocado red mite Oligonychus yothersi (Mcgregor) (Acari: Phytoseiidae, Tetranychidae). — Chilean J. Agric. Res. 69: 160-170.

Ripa R., Rodríguez F., Rojas S., Larral P., Castro L., Ortúzar J., Carmona P. \& Vargas R. 1999: Citrus Pests, their Natural Enemies and Management. INIA Books Collection $\mathrm{N}^{\mathrm{o}} 3.151$ pp. [in Spanish].

Rojas R. 2005: Biological Control of Pests in Chile. History and Progress. INIA Books Collection No12, 123 pp. [in Spanish].

Stenseng L., Skovgard H. \& Holter P. 2003: Life table studies of the pupal parasitoid Urolepis rufipes (Hymenoptera: Pteromalidae) on the house fly Musca domestica (Diptera: Muscidae) in Denmark. - Environ. Entomol. 32: 717-725.

Ulusoy M.R. \& Uygun N. 1996: Two new potential pests in the East Mediterranean Region of Turkey: Aleurothrixus floccosus (Maskell) and Paraleyrodes minei Iaccarino (Homoptera, Aleyrodidae). — Turk. J. Entomol. 20: 113-121.

Ulusoy M.R., Vatansever G., Erkilic L. \& Uygun N. 2003: Studies on Aleurothrixus (Maskell) (Homoptera, Aleyrodidae) and its parasitoid, Cales noacki Howard (Hymenoptera, Aphelinidae) in the East Mediterranean region of Turkey. $-J$. Pest Sci. 76: 163-169.

Urbaneja A., Sánchez E. \& Stansly P. 2007: Life history of Eretmocerus mundus, a parasitoid of Bemisia tabaci, on tomato and sweet pepper. - BioControl 52: 25-39.

Vargas R., Olivares N. \& Cardemil A. 2005: Postembryonic development and life table parameters of Typhlodromus pyri Scheuten, Cydnodromus californicus McGregor) (Acarina: Phytoseiidae) and Brevipalpus chilensis Baker (Acarina: Tenuipalpidae). - Agric. Téc. 65: 147-156 [in Spanish, English abstr.].

VatanSEVER G.S. \& Ulusoy M.R. 2009: The effects of different temperatures and diets on the biology of Cales noacki Howard (Hymenoptera: Aphelinidae), a parasitoid of the citrus woolly whitefly. - Turk. J. Agric. For. 33: 267-275.

Vivas A.G. 1992: Present Status of Whitefly on Citrus in Spain, and Control Guidelines. Seminaire de la commission de technique, le 2 et 3 Septembre, Antalya, Turquie. pp. 1-19.

ZAR J.H. 2006: Biostatistical Analysis. 5 ed. Englewood Cliffs, Prentice Hall, New Jersey, 960 pp.

Received August 1, 2013; revised and accepted December 2, 2013 Prepublished online February 21, 2014 